\section{Tamara Mikolič Južnič, \\ Nike K. Pokorn}

University of Ljubljana, Slovenia
2021, Vol. 18 (1), 15-35(222)

revije.ff.uni-lj.si/elope

https://doi.org/10.4312/elope.18.1.15-35

UDC: $81 ' 253$

\title{
In Search of the Essential Competences for Overcoming Language Barriers in Public Services
}

\begin{abstract}
It is argued in the article that despite the relatively strong presence of English in Slovenia, the use of English as a lingua franca (ELF) alone does not guarantee access to quality public services. To supplement the use of ELF interpreting support is needed, in particular in high-risk situations. A step in this direction was the certification of a national vocational qualification for community interpreters for Albanian in 2020. Since at the same time a new vocational profile for intercultural mediators was created, which also aims to assist the inclusion of migrants in the Slovene society, we investigated the differences between these two profiles by comparing the competences defined in both. The results show that despite some overlaps Slovene vocational standards for both professions differ significantly: while transfer and linguistic competences are central to community interpreter's profile, conflict resolution and mediation competence figure more prominently in the intercultural mediator's profile.
\end{abstract}

Keywords: linguistic inclusion, national vocational qualification, community interpreting, intercultural mediation, competences

\section{Iskanje ključnih kompetenc za premagovanje jezikovnih ovir v javnih službah}

\section{IZVLEČEK}

Članek prikazuje, kako kljub razmeroma močni prisotnosti angleščine v Sloveniji raba angleščine kot lingue france sama po sebi ne omogoča jezikovne vključenosti in ne zagotavlja dostopa do kakovostnih javnih storitev. Ob angleščini kot lingui franci je potrebna še tolmaška podpora, zlasti v visokorizičnih situacijah. Korak v to smer predstavlja nacionalna poklicna kvalifikacija za skupnostne tolmače za albanski jezik, sprejeta leta 2020. Ker je hkrati nastala tudi nacionalna poklicna kvalifikacija za medkulturne mediatorje, ki je prav tako namenjena podpori vključevanja migrantov v slovensko družbo, v članku s primerjavo poklicnih kompetenc raziščeva razlike med tema dvema profiloma. Rezultati nakazujejo, da se, kljub nekaterim podobnostim, slovenska poklicna standarda izrazito razlikujeta: medtem ko sta prevodna in jezikovna kompetenca osrednji v profilu skupnostnega tolmača, osrednje mesto v profilu medkulturnega mediatorja zavzemata kompetenci razreševanja konfliktov in mediacije.

Ključne besede: jezikovno vključevanje, nacionalna poklicna kvalifikacija, skupnostno tolmačenje, medkulturna mediacija, kompetence 


\section{Introduction}

The English language is the most widespread and only true global lingua franca in the contemporary world (see e.g., Mauranen 2014). Moreover, the attitude towards English, at least in the EU, seems to be overwhelmingly positive (see Henry 2016): according to European Commission's survey of 26.751 respondents in 2012, two thirds of Europeans (67\%) considered English as one of the two most useful languages in the EU. Although Slovenia was one of the eight EU member states where English was not the first foreign language of the population (Croatian was reported as the foreign language most commonly spoken in Slovenia (61\%)), a very high percentage of surveyed Slovenes (59\%) stated that English is a language that they know well enough in order to be able to have a conversation (European Commission 2012, 21).

Despite these results, it will be argued in this article that in Slovenia the use of English as a lingua franca (ELF) does not enable linguistic inclusion, in particular to the most vulnerable groups of migrants, and that it does not guarantee access to quality public services. The use of English as a lingua franca needs to be supplemented by community interpreting, in particular in high-risk situations. However, in order to provide support that leads to quality services, the profession of community interpreting needs to be defined and the individuals practicing it need to undergo a certification process.

This article presents the new vocational certifications for community interpreters and intercultural mediators in Slovenia, and compares the list of competences indicated in three documents defining the profession of community interpreter to three documents defining the profile of intercultural mediator, and highlights the main differences.

The article starts with an overview of the existing research reporting on cases and situations in Slovenia in which ELF did not enable the establishment of successful communication. Next the introduction of community interpreting is proposed as a more suitable communication strategy in high-risk situations, such as healthcare settings, allowing equal access to public services to users who do not speak or understand Slovene. Subsequently, the ongoing discussion on the difference between community interpreters and intercultural mediators is addressed. This is followed by a description of the Slovene vocational qualification for community interpreters for Albanian, which also envisages a certification exam for the candidates. Then an analysis of selected documents comparing community interpreters and intercultural mediators in terms of competences is presented, and the implications of the results are discussed.

\section{When the Use of English is Not the Solution - Review of the Literature}

Although the results of the European Commission's survey show that in Europe the attitude towards the use of English was overwhelmingly positive in 2012, the status of English in Europe is changing and some researchers argue that it is no longer seen only as the language that enhances opportunities to take part in the global market, but is sometimes also viewed as a threat to the national languages in Europe (Linn, Bermel, and Ferguson 2015). In addition 
to that, Michele Gazzola and Francois Grin in their article "Is ELF more effective and fair than translation? An evaluation of the EU's multilingual regime" (2013) argue that "the use of translation and interpreting, though not free, remains more effective (and at a reasonable cost) than a monolingual regime based on English alone; it also more fair than a monolingual regime which unavoidably privileges native speakers" $(2013,93)$.

Taking Slovenia as the case in point, we argue here that not only are translation and interpretation fairer than the imposition of the use of English, particularly considering that interpreting is also envisaged by the Slovene Administrative Procedure Act (ZUP; PISG Legal Information System 2013), ${ }^{1}$ but that very often the complexity of interlingual and intercultural encounters in the contemporary western world and the varieties of different linguistic and cultural backgrounds of the speakers attempting to establish linguistic contact make translation and interpretation the only means of enabling successful communication.

In 2016 a survey of linguistic profiles of migrants in Slovenia applying for international protection was made, in an attempt to define the preferred mediation strategy of this group of migrants (Pokorn and Čibej 2018a). They were asked if they prefer to use interpreters or machine translation tools, practice intercomprehension, use a lingua franca or learn the dominant language of the receiving culture. With the help of a questionnaire, data were gathered on linguistic profiles of 127 residents of asylum seeker centres in Slovenia, and interviews were conducted with a representative group of 38 asylum seekers speaking ten different mother tongues (Arabic, Farsi, Dari, Russian, Kurdish, Albanian, Bosnian, French, Ibo and English).

In the questionnaire the asylum seekers were asked to indicate the level of proficiency in any foreign languages they believed they had knowledge of (shown in Figure 1). The results indicated that English was by far as the most widespread foreign language among this population.

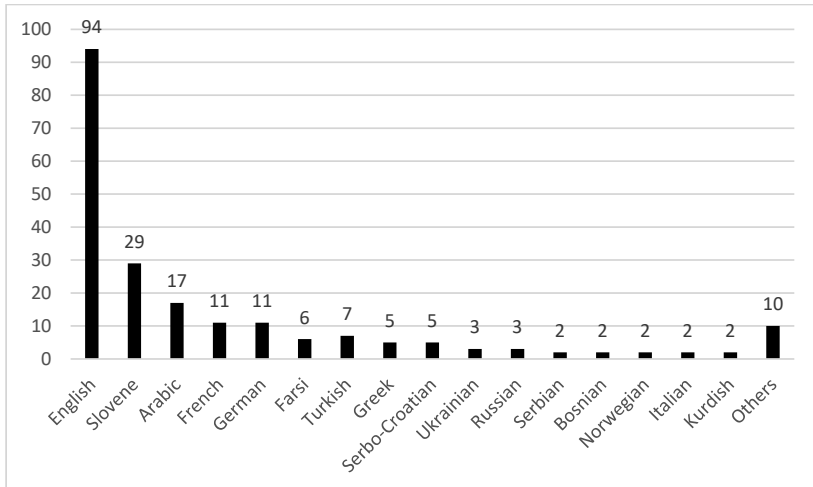

FIGURE 1. Foreign languages indicated by the residents of the Slovene asylum seeker centres in October 2016 (Pokorn and Čibej 2018a).

ZUP provides legal grounds for the provision of interpreting services. In article 62 (7), inter alia, it stipulates the following: "Parties and other participants to the procedure who do not speak the language in which the procedure is conducted, or who are unable to use it because of disability, shall have the right to follow the course of the procedure through an interpreter. The authority shall be obliged to instruct such persons of such possibility." (ZUP, 36). 
Further results showed that English is also used in a variety of settings in Slovenia: in the representative group of 38 interviewees, 25 migrants indicated that they spoke English, and that they use this language always $(n=24)$ or often $(n=1)$ in their everyday contacts with other people in Slovenia. We asked them to rate their proficiency in listening, reading, speaking and writing on a scale of 1 (poor) to 5 (excellent), and the results are shown in Figure 2.

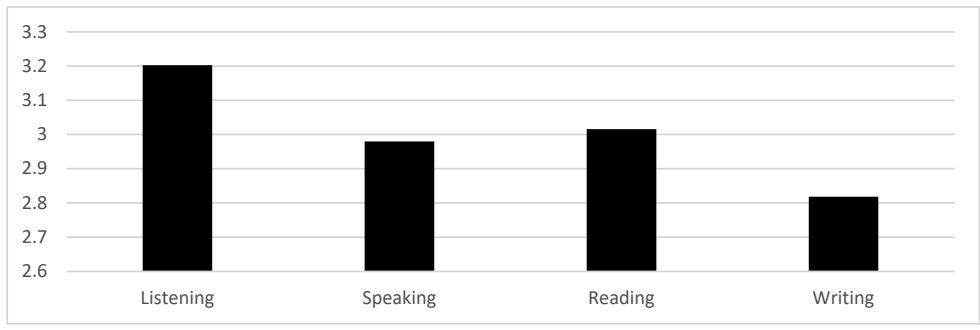

FIGURE 2. Interviewees' self-reported proficiency in English.

Two thirds of the interviewees thus stated that they use English for communication in Slovenia and indicated that their knowledge of the language in all four skills is good (average grade was 3). However, in the interviews they also pointed out that English was not useful in all settings and environments: for example, the refugees and asylum seekers noticed that in Slovenia the older generations do not speak English, and that English is also rarely spoken in rural areas. Similar results were obtained by Fiedler and Wohlfarth (2018), who interviewed twenty migrants in Germany with English in their language repertoires. The migrants reported a major discrepancy in English-language proficiency between young and old people, and between different urban centres. Similarly to the migrants in Slovenia, migrants interviewed by Fiedler and Wohlfarth did not see English as a reliable or viable option for communication in Germany.

Another study (Pokorn and Čibej 2018b) examined the mediation strategies of foreign teachers at two international schools working in Slovenia. The results showed that although the interviewees found English to be the most useful foreign language in Slovenia, the use of English failed in healthcare settings, where they would often encounter providers, in particular nurses, who did not speak English. This observation was corroborated by another nation-wide survey among healthcare workers in Slovenia in 2016, which gathered responses of 564 healthcare providers (Milavec Kapun and Pokorn 2019). The survey responses of 331 nurses showed that, regardless of the level of education attained, nurses rated their foreignlanguage competence considerably lower than doctors or dentists, ${ }^{2}$ and in fact as many as 101 nurses (36\%) indicated that their knowledge of English was elementary.

Thus, in the Slovene healthcare system the use of English as a lingua franca does not guarantee successful communication, due to the lack of knowledge of this language among healthcare providers. Moreover, it has been observed that some patients reject the use of ELF in highrisk healthcare situations. Pokorn, Matičič and Pokorn (2009) describe such a case: in 2008,

2 Only $3 \%$ of doctors and 16\% of dentists indicated an elementary knowledge of English (see Milavec Kapun and Pokorn 2019, 51). 
a 15-year-old refugee from Afghanistan, whose parents were killed in Afghanistan, was admitted to the Department of Infectious Diseases, University Clinical Centre Ljubljana. He had a knowledge of some basic English and was accompanied by a female Slovene guardian, assigned to him by the detention centre, who spoke English with him. He was diagnosed with a life-threatening disease, but the patient refused all medical procedures and did not want to communicate with healthcare providers who tried to speak to him in English. The treating physician was convinced that the patient would need someone to explain the risks to him but was unable to communicate with him effectively. Because no support was provided to medical doctors in such cases, the physician contacted an Afghan interpreter working for the Slovene mission at the NATO base in Afghanistan. The interpreter had a long telephone conversation with the patient in his native language - and was eventually able to change his mind. The patient started to take the prescribed medications, and in the following days his mood picked up and his medical condition improved significantly. There is no doubt that the treatment of the patient was successful largely because communication in his native language was enabled.

Research thus shows that in high-risk situations, in particular in healthcare settings, the support of interpreters is sometimes vital. Since in Slovenia there is no training for community interpreters for the languages of newly arrived migrants, interpreting in different publicservice settings is sometimes provided by relatives or friends of patients (i.e., the so-called ad hoc interpreters), or by individuals who support themselves by interpreting but who have no training for the profession of interpreters. Some of them, with the help of intensive self-study, practice interpreting according to the international standards for community interpreters, others do not. In order to raise the level of service, the national vocational certification for community interpreters was formed.

\section{Competing Profiles}

The need for bridging linguistic and cultural differences has become ever more pressing in Europe in recent years, which have been marked by an increase in migration. Countries whose populations have been more prone to emigration until recently (such as Italy or Greece; see Schuster 2005, Apostolou 2012) or that have only faced immigration from certain countries in the neighbourhood (such as Slovenia in relation to the former Yugoslav republics and territories, see Gorjanc and Pokorn 2013), suddenly encountered in their midst a multitude of immigrants, coming from different cultures and speaking different languages, which became quite a challenge, especially in official or high-risk situations such as healthcare. This often called for ad hoc solutions that resulted in a rather confusing state of affairs in the EU countries in terms of legislation and definitions of the names and roles of the professionals (and non-professionals) who were employed to overcome emerging language barriers. As a result, two profiles started to compete in the same field, i.e., the community interpreter and the intercultural mediator.

The apparent confusion regards both the name of the profession and the nature of the work performed: on the one hand, the terms community interpreter and intercultural mediator 
(and their various more or less synonymous forms ${ }^{3}$ ) are used in different ways by different people; on the other hand, their work and competences are also understood differently. An in-depth discussion of the problem is outside the scope of this article: here we refer to just a few selected articles made by some scholars who attempted to distinguish the two profiles, and pay a particular attention to two intrinsically divergent points of view. Proponents of both sides recognize the need in the market and society for professionals whose job would be to help migrants access services which are offered in the languages of the host country and in which they are not proficient. But while proponents of intercultural mediators (Theodosiou and Aspioti 2015, Verrept 2019) largely reject community interpreters - claiming that they only transpose linguistic elements from one language into another, separating language from the cultural content of the communication, which, according to them, is the domain of the intercultural mediator - others, such as Pöchhacker (2008), Martín and Phelan (2010) and Pokorn and Mikolič Južnič (2020), for instance, reject such oversimplifications of the competences of community interpreters, but nevertheless acknowledge the need for both profiles. They argue that interpreting services should be offered by trained professionals (i.e., community interpreters), while other tasks, such as informing and assisting the migrants in accessing services and integrating in the host society, which involve mainly dyadic, not triadic (i.e., interpreted) communication, should be carried out by intercultural mediators.

Furthermore, Pöchhacker (2008) and Martín and Phelan (2010) argue that terminological indeterminacy reflects negatively on the professionalization of the two profiles. We believe that the difference between intercultural mediators and community interpreters should also not be boiled down just to a question of ethical positioning (Pokorn and Mikolič Južnič 2020).

As a consequence of this indeterminacy, as Martín and Phelan (2010) observe, in France, Italy, parts of Belgium and Germany, the two terms are often used interchangeably, without a real distinction of their roles. In Italy, the situation is particularly complex, as the term intercultural mediator is used as the name of at least three very different profiles, i.e., the term is used as a synonym of community interpreters; it may define specialists in conflict prevention and resolution, or it may be used for community integration facilitators and non-professional interpreters (see Pokorn and Mikolič Južnič 2020: 86-88). In Belgium, according to Cox (2015), both profiles coexist and intercultural mediators and community interpreters often work in the same hospitals, though abiding by different codes of ethics, especially in terms of advocacy.

Additionally, it should be specified that community interpreting is a certified profession in a number of countries and defined within the international standard "Interpreting - Guidelines for community interpreting" (ISO 13611:2014) as "oral and signed communication that enables access to services for people who have limited proficiency in the language of such services".

Community interpreters are also called public service interpreters, interpreters in institutional discourse, dialogue interpreters, or liaison interpreters. Intercultural mediators have been named also linguistic mediators, linkworkers, ethnic minority health counsellors, bridgepersons, intercultural interpreters, and so on (see Pokorn and Mikolič Južnič (2020) for further details). 


\subsection{Situation in Slovenia}

In Slovenia, the need for a profile of an interpreter who would be able to respond to the challenges of a new linguistic landscape in the country was recognized in the mid 2000s (see Pokorn and Mikolič Južnič 2021). Already at that time, the translation studies community defined a community interpreter ("skupnostni tolmač") as a trained or an untrained individual who performs oral or signed translational activity from and into the societal language, and thus assists individuals who are not proficient in the societal language to access the services provided by public institutions (see also Pokorn, Viezzi, and Radanović Feldberg 2020, 10). Efforts for the professionalization of community interpreting began as early as in 2007, when the University of Ljubljana joined an EU-funded project with the aim of creating a curriculum for medical interpreting, which culminated in the preparation of a one-year community interpreter training programme (Gorjanc 2013). Unfortunately, lack of funding and qualified teachers prevented the programme from being launched (Gorjanc and Pokorn 2013).

In an effort to overcome such deficiencies, a short specialization course for sworn interpreters was introduced in 2018/19 by the University of Ljubljana (Maček and Schlamberger Brezar 2019). Furthermore, another project was undertaken in 2019 by four universities from Italy, Norway, Greece and Slovenia, in order to train teachers for community interpreting, especially for languages that are traditionally not taught in Slovene universities: in Slovenia, the TRAMIG project (Training newly arrived migrants for community interpreting and intercultural mediation, see Pokorn, Viezzi, and Radanović Feldberg 2020) trained community interpreter teachers for Albanian, Arabic and Persian to work in tandems with local interpreting teachers with the purpose of harnessing both the expertise of the interpreter trainers of the University of Ljubljana, and the language expertise in Albanian, Arabic and Persian of the volunteers with a migration background.

Intercultural mediators appeared in Slovenia in the last decade in connection with several projects mainly carried out by non-academic institutions and organizations (see Lipovec Čebron and Škraban 2020), which resulted in the absence of systematic training. With the exception of a few short courses organized by the International Organization for Migration in Slovenia and the National Institute of Public Health in Slovenia, no plans to establish training of intercultural mediators seem to be currently under way. At present in Slovenia there seem to be two understandings of the profile of intercultural mediator. One is defined in the National Vocational Qualification (described below), and the other in some of the publications of National Institute of Public Health. The publications of the National Institute of Public Health, such as Bofulin et al. (2016), promote intercultural mediators at the expense of interpreters, claiming that "interpreting transfers the language, while mediation transfers the cultural meaning" (Bofulin et al. 2016, 2334), despite the fact the research leaves no doubt that language and culture are inseparable and that linguistic and cultural mediation are intrinsic to interpreting (see, e.g., Falbo 2013).

\footnotetext{
All translations are our own unless otherwise indicated. It should be noted that next to the quoted part, the authors refer to Bowen $(2001,8)$, misinterpreting her words: Bowen does not speak of intercultural mediators, but rather discusses how the roles and tasks of interpreters can be understood and expanded in different contexts by different users of their service.
} 
The understanding of the profile of an intercultural mediator found in Bofulin et al. (2016) is modelled after the definition of the tasks of intercultural mediators as presented recently by Verrept (2019), which is translated into Slovene in Huber and Lipovec Čebron (2020). Verrept reduces "linguistic interpreting ('interpreting' in the strict sense)" to a 'translation machine model', and places it to the bottom step of his "ladder model" in which higher functions of intercultural mediation include resolving misunderstandings, cultural brokerage, helping provider/patient take up their roles and advocacy. Similarly, Lipovec Čebron and Škraban $(2020,38)$ argue that the aim of intercultural mediators is "to assure equity and reduce language and cultural barriers in access to public services for people who do not master societal language", supporting the notion that the characteristic that distinguishes them from community interpreters is their ethical positioning, in which advocacy has a central position. As discussed in Pokorn and Mikolič Južnič (2020), however, the reasons for the emergence of this kind of understanding of a new profile of intercultural mediators seem to be much more complex, including the lack of trained interpreters for the languages of newly arrived migrants, the fight for dominance in the training of migrants' languages specialists and the sometimes unreasonable expectations of healthcare providers. However, there exists also an alternative understanding of the role and profile of intercultural mediators, where intercultural mediators are defined as integration facilitators, i.e., individuals who assist migrants when they lack cultural awareness and understanding of the system and, consequently, cannot access and benefit from quality basic social services, education, primary health care, fair trial and political participation in the host country (Martín and Phelan 2010; Pokorn, Viezzi, and Radanović Feldberg 2020, 11).

\section{The Certification}

Apart from training, an important milestone was achieved in 2020 with the development of two occupational standards: the National Vocational Qualification for Intercultural Mediator and the National Vocational Qualification for Community Interpreter for Albanian.

Within the European Qualification Framework and the Slovene Qualification Framework, the National Vocational qualification (NVQ) "is a formally recognised work-related, competence-based qualification, which reflects the skills and knowledge needed to do a job effectively" (RIC - National Examination Centre). If they pass the exam, the certificate a candidate gets "shows that a candidate is competent in an area of work or individual segments of work, within an area at a certain level of achievement" (RIC - National Examination Centre). NVQs are based on national occupational standards, documents that serve as the basis for designing different pathways to achieve professional qualifications. Occupational standards determine the content of NVQs by defining the knowledge, skills and professional competence necessary to practice a profession. Catalogues of professional knowledge (CPKS), which are always prepared parallel to the NVQs, further define the procedures, requirements, and examinations, as well as repeating the competences listed in the relative NVQs (Pokorn, Viezzi, and Radanović Feldberg 2020, 52-57). One of the most important advantages of NVQs is that they give individuals a possibility to validate their skills and knowledge obtained through the pursuit of their occupation, volunteer work, leisure activities, participation in non-formal training programs, self-learning etc., i.e., they do not normally entail any 
obligatory formal education. The standards and the catalogues are formulated by a group of invited experts led by a senior officer of National Institute for Vocational Education and Training, usually taking into account similar qualifications abroad. For example, the NVQ for community interpreters includes in its reference list, among others, the international standard ISO 13611: 2014 Guidelines for Community interpreting (2014), the document developed by the European Network for Public Service Interpreters and Translators Public Service Interpreting: minimally required competence in terms of knowledge, skills and attitudes, California Standards for Healthcare Interpreters (2002), the US National Standards of Practice for Interpreters in Healthcare (2005), and the Canadian National Standard Guide for Community Interpreting Services (HIN 2007). The NVQ for intercultural mediators, however, does not refer to any international standards or international literature (with the notable exception of Ethnicity and Globalization (Castles 2000) and Guide for intercultural mediation in health care (Verrept and Coune 2016)) and includes in its reference list either works by members of the expert committee responsible for the formation of NVQ for intercultural mediators (for example, the monograph Integracija kot clovekova pravica [Integration as a human right] (Vrečer 2007)) or verified educational programs for learning Slovene or the integration of migrants, applicants for international protection and refugees into Slovene society.

In the next section we highlight the differences in competences between the two profiles as defined in the Slovene CPKSs, and the main characteristics of the two profiles are summarized. The text used for the analysis is the English translation of CPKSs by Nataša Hirci, published in Pokorn, Viezzi, and Radanović Feldberg (2020).

\subsection{Slovene National Vocational Qualification 'Community Interpreter for Albanian'}

The Slovene NVQ 'Community Interpreter for Albanian' is included in the KLASIUS 5 classification system within the wider category of Language Acquisition (other, foreign, sign language, translation studies). In the Standards for Professional Knowledge and Skills and in the Catalogue of Professional Knowledge and Skills, we find a list of the key tasks and knowledge and skills necessary to obtain the certification, presented in Table 1.

TABLE 1. Knowledge and skills of the NVQ 'Community interpreter for Albanian'.

\begin{tabular}{|l|l|}
\hline Key tasks & Knowledge and skills \\
\hline Consecutive & $\bullet$ interpret and translate texts connected to the interpreting task \\
interpreting, & from Albanian to Slovene and vice versa \\
chuchotage and & $\bullet$ interpret and translate texts connected to the interpreting task \\
sight translation plus & (e.g., medical examination report, instructions for follow-up \\
translation of short & treatment) as accurately as possible with no unnecessary addition \\
texts relevant for & $\begin{array}{l}\text { or omission } \\
\text { interpreting }\end{array}$
\end{tabular}

5 KLASIUS (https://www.stat.si/Klasius/Default.aspx?id=1) is the obligatory standard used in Slovenia for classifying activities in education and training (including the field of national vocational qualifications). 


\begin{tabular}{|c|c|}
\hline & $\begin{array}{l}\text { - adhere to basic features of interpreting, i.e., initial introduction } \\
\text { of all participants, positioning, turn-taking } \\
\text { - select and provide interpreting suitable in the given } \\
\text { circumstances: consecutive interpreting for a dialogue or a lengthy } \\
\text { exchange supported by note-taking, chuchotage } \\
\text { (for lectures) or sight interpreting } \\
\text { - use different techniques of note-taking } \\
\text { - recognize situations when a primary-speaker position has to } \\
\text { be assumed and communication interrupted (e.g., asking for } \\
\text { clarification, pointing out cultural misunderstanding) } \\
\text { - respect different roles of participants (distinguish between the } \\
\text { role of an interpreter and that of a healthcare provider, etc.) } \\
\text { • invest into additional (self)training and their own professional } \\
\text { development }\end{array}$ \\
\hline $\begin{array}{l}\text { Interpreting and } \\
\text { translation of } \\
\text { discourse in different } \\
\text { registers and from } \\
\text { different fields }\end{array}$ & $\begin{array}{l}\text { - use Albanian for different language users and adapt it to their } \\
\text { age, gender, regional background as well as socio-economic status } \\
\text { • understand different language varieties of Albanian (e.g., } \\
\text { different dialects, idiomatic expressions, etc.) and different } \\
\text { registers (e.g., less formal spoken discourse, formal standard } \\
\text { language, etc.) } \\
\text { - use register appropriate for the given situation and the type of } \\
\text { discourse } \\
\text { • use terminology typical of the interpreted field, i.e., terminology } \\
\text { used in healthcare or educational settings, administrative } \\
\text { procedures or police proceedings } \\
\text { • know the field they interpret (e.g., know the basics of } \\
\text { healthcare, asylum procedures, educational system in Slovenia, } \\
\text { administrative and police proceedings, etc.) } \\
\text { - respect cultural differences and respond properly } \\
\text { - understand specific behaviour, gestures, tone of verbal and non- } \\
\text { verbal communication } \\
\text { - show awareness of different culture-specific roles of professionals } \\
\text { and identities in different cultures }\end{array}$ \\
\hline $\begin{array}{l}\text { Use suitable tools } \\
\text { and technologies } \\
\text { for translation and } \\
\text { interpreting }\end{array}$ & $\begin{array}{l}\text { - use technical equipment for remote interpreting (telephone, } \\
\text { web applications) } \\
\text { - understand the prospects and limitations of machine translation } \\
\text { and interpreting } \\
\text { - work with word processing software } \\
\text { - efficiently use different computer-assisted programmes for } \\
\text { documents, word processing and terminology management }\end{array}$ \\
\hline
\end{tabular}




\begin{tabular}{|l|l|}
\hline $\begin{array}{l}\text { Acquire additional } \\
\text { information for the } \\
\text { field they interpret }\end{array}$ & $\begin{array}{l}\text { - recognize their own information and documentation needs } \\
\text { - obtain additional information for the interpreted field } \\
\text { - seek additional information on language use and specific } \\
\text { terminology for the interpreted field } \\
\text { - make efficient use of document and terminology sources (e.g., } \\
\text { terminology databases, language corpora, etc.) } \\
\text { - properly assess reliable documents and sources available online } \\
\text { and in other media } \\
\text { - create their own terminology databases needed for the } \\
\text { interpreted field }\end{array}$ \\
\hline $\begin{array}{l}\text { Communicate and } \\
\text { establish contacts } \\
\text { with colleagues, } \\
\text { professionals and } \\
\text { end-users }\end{array}$ & $\begin{array}{l}\text { - are polite, respectful and tactful } \\
\text { other prejudices and refrain from them in interpreting and } \\
\text { communication with their clients } \\
\text { • work efficiently with people from different cultures, respect } \\
\text { other cultures and recognize cultural differences } \\
\text { - respect the rules of collaboration with other participants of } \\
\text { interpreting (e.g., in healthcare settings) } \\
\text { - know how to obtain information on the nature of the meeting/ } \\
\text { conversation to be interpreted, and know how to agree with other } \\
\text { participants on the behaviour protocol } \\
\text { and positioning of all the participants }\end{array}$ \\
\hline
\end{tabular}

\subsection{National Vocational Qualification 'Intercultural Mediator'}

Unlike the above NVQ, the NVQ 'Intercultural Mediator' belongs to the wider category of Social work and counselling in KLASIUS, which is reflected in the catalogue of standards on professional knowledge and skills for the NVQ 'Intercultural mediator' (translated into English in Pokorn, Viezzi, and Radanović Feldberg 2020, 61-75) and in the specific key tasks and skills, given in Table 2.

TABLE 2. Knowledge and skills of the NVQ 'Intercultural Mediator'.

\begin{tabular}{|l|l|}
\hline Key tasks & Knowledge and skills \\
\hline $\begin{array}{l}\text { Establish and } \\
\text { facilitate intercultural } \\
\text { communication } \\
\text { within and outside } \\
\text { of institutions related } \\
\text { to the integration of } \\
\text { migrants }\end{array}$ & $\begin{array}{l}\bullet \text { provide intercultural and language mediation in Slovene and } \\
\text { employment, healthcare and social security, housing, public } \\
\text { admintration, etc. }\end{array}$ \\
& $\begin{array}{l}\bullet \text { understand most common barriers to the integration of } \\
\text { migrants in Slovenia } \\
\text { - use and adapt terminology on intercultural mediation }\end{array}$
\end{tabular}




\begin{tabular}{|c|c|}
\hline & $\begin{array}{l}\text { - show awareness of social, cultural and economic characteristics } \\
\text { (including linguistic, religious, political and other) of at least one } \\
\text { foreign country/territory and constantly strive to improve their } \\
\text { knowledge through lifelong learning } \\
\text { - understand how public services work } \\
\text { - understand different beliefs and practices of the migrants in } \\
\text { need of intercultural mediation, and understand culture-specific } \\
\text { beliefs and practices present within and outside of institutions in } \\
\text { Slovenia }\end{array}$ \\
\hline $\begin{array}{l}\text { Provide information } \\
\text { to } \\
\text { target groups/ } \\
\text { migrants on } \\
\text { their rights and } \\
\text { duties in } \\
\text { Slovenia }\end{array}$ & $\begin{array}{l}\text { - understand the structure and activities of state and public } \\
\text { administration and other organizations in Slovenia, and the } \\
\text { migrants' territories/countries of origin for whom intercultural } \\
\text { mediation is provided } \\
\text { - know categories or statuses of migrants and understand the } \\
\text { rights and duties of migrants in Slovenia } \\
\text { - assist migrants to get acquainted with the structure and activities } \\
\text { of state and public administration and other organizations in } \\
\text { Slovenia } \\
\text { - assist migrants to exercise their rights and duties in Slovenia } \\
\text { related to education, employment, healthcare, administrative } \\
\text { procedures, social security, etc. } \\
\text { - understand social, cultural and economic characteristics } \\
\text { (including linguistic, religious, political and other) of at least one } \\
\text { foreign country/territory of origin of the migrants and improve } \\
\text { their knowledge in the process of lifelong learning }\end{array}$ \\
\hline $\begin{array}{l}\text { Promote } \\
\text { intercultural } \\
\text { dialogue between } \\
\text { migrants and other } \\
\text { members of the } \\
\text { Slovene society }\end{array}$ & $\begin{array}{l}\text { - understand the importance of integration as a two-way process } \\
\text { and show an ability to convey this to the target group and other } \\
\text { residents of Slovenia in the process of intercultural mediation } \\
\text { - promote social networking } \\
\text { - understand the importance of intercultural dialogue in various } \\
\text { fields: cultural, social, economic, etc. } \\
\text { - respect and promote gender equality } \\
\text { - understand migration processes and the importance of migrant } \\
\text { integration } \\
\text { - make workers in various organizations and other citizens aware } \\
\text { of the cultures of migrants and facilitate them in developing an } \\
\text { appropriate attitude towards the cultural habits, practices and } \\
\text { beliefs of the migrants }\end{array}$ \\
\hline
\end{tabular}

\section{The Study}

The aim of the empirical part of this study was first to identify which competences in the above-presented NVQs are considered more central for each of the two profiles, and second, if the core competences of each profile can be found in the documents defining the two profiles 
in other countries. We first hypothesize that while the core competences for both profiles are similar, the importance of each competence for one or the other profile differs. Second, we argue that while the competences of community interpreters as defined in the Slovene NVQ are in line with those listed in international standards for community interpreting, the competences of intercultural mediators defined in the Slovene NVQ differ from those found in the lists of competences in documents on intercultural mediators understood as culturally enhanced interpreters/advocates, and are more aligned with the profiles of intercultural mediators understood as integration advisors for the migrants.

\subsection{Corpus}

To gain insight into the differences between the two profiles, i.e., the profile of community interpreters and that of intercultural mediators, we have compared the two Slovene Catalogues of Professional Knowledge and Skills (CPKS) with each other as well as with two sets of documents concentrating on the two profiles issued by public bodies or professional associations. The English translations of the CPKS for community interpreters and intercultural mediators are available in Pokorn, Viezzi, and Radanović Feldberg (2020, Appendix 6). For comparison we have selected four international documents: two competence profile documents for community interpreters, and two competence profile documents for intercultural mediators, all of which were issued recently in the EU. We are aware of the existence of competence documents for community interpreters, such as the Canadian National Standard Guide for Community Interpreting Services or of the US competence models for healthcare interpreters, one of the largest subgroups of community interpreters, such as, for example, Core competencies for health care interpreters (Refki, Avery and Dalton 2008). Our focus on the EU is intentional, as the situation in the USA and other countries like Canada and Australia with a long history of receiving migrants with no knowledge of the dominant or official language of the state and assisting them to access public services differs from that in the EU, where some of the Member States are encountering problems associated with mass migration for the first time. In addition to this, in order to minimize the subjectivity bias we did not select the competence documents that were the reflection of the views of an individual or a pair of scholars (e.g., Martín and Phelan 2010 or Verrept and Coune 2016), but focused only on those documents that were an expression of an association, NGO or international project.

The documents in the corpus are thus the following:

a) two catalogues of standards on professional knowledge and skills:

- A Catalogue of Professional Knowledge and Skills for Community Interpreters for Albanian (henceforth CPKS CI);

- A Catalogue of Professional Knowledge and Skills for Intercultural Mediators (henceforth CPKS IM);

b) two competence profile documents for community interpreters:

- Public Service Interpreting: minimally required competence in terms of knowledge, skills and attitudes by the European Network for Public Service Interpreting \& Translation (henceforth ENPSIT); 
- ISO Standard 13611/2014: Interpreting - Guidelines for community interpreting (henceforth ISO 13611/2014);

c) two competence profile documents for intercultural mediators:

- Intercultural Mediator Profile and Related Learning Outcomes, Erasmus+ project TIME (Train Intercultural Mediators for a Multicultural Europe, 2015) (henceforth TIME);

- Criteria for Approving Programs to Qualify Mediators for IMI Inter-Cultural Certification by the International Mediation Institute (henceforth IMI ICC).

\subsection{Method}

The selected texts were analysed in terms of competences with the computer-assisted qualitative data analysis software NVivo. Five competences identified as the most relevant in previous research (Pokorn and Mikolič Južnič 2020) were used as nodes. Items (sentences, phrases) were analysed so that each coded instance represents a specific type of knowledge or skill associated with a competence, while taking into account the amount of detail and the length of description. If a type of knowledge and/or skill is associated with different types of competences, such items were coded with multiple nodes. The analysed competences are the following:

- Transfer competence

- Linguistic competence

- Thematic competence

- Cultural competence

- Conflict resolution and mediation competence

Finally, the aggregated qualitative data for each competence was analysed to determine its relative importance.

\section{Comparison of Competences}

The qualitative analysis of the texts yielded the results summarized in Table 3, which shows a comparison of the number of coded items for each category in every text for each of the analysed competences. Below we concentrate on a detailed comparison of the way competences are represented in the analysed texts.

In Table 3 we notice that overall there are considerable differences in the number of coded instances for each competence in each document. Cultural, thematic and linguistic competence are present in all documents, while transfer competence is not mentioned in IMI ICC, and conflict resolution and mediation competence is not present in ENPSIT. The most frequently coded competence by far is the cultural competence (with a sum of 90 instances), followed by the transfer competence, which refers to interpreting, translation, etc. $(\mathrm{N}=59)$, and the thematic competence (i.e., factual knowledge about the institutions and fields in which community interpreters/intercultural mediators work; N=57). Similarly to thematic competence, linguistic competence, is also present in all documents $(\mathrm{N}=50)$, albeit 
TABLE 3. Comparison of the coded competences in the analysed documents.

\begin{tabular}{|l|c|c|c|c|c|}
\hline & $\begin{array}{l}\text { Conflict resolu- } \\
\text { tion and media- } \\
\text { tion competence }\end{array}$ & $\begin{array}{l}\text { Cultural } \\
\text { compe- } \\
\text { tence }\end{array}$ & $\begin{array}{l}\text { Thematic } \\
\text { compe- } \\
\text { tence }\end{array}$ & $\begin{array}{l}\text { Linguistic } \\
\text { compe- } \\
\text { tence }\end{array}$ & $\begin{array}{l}\text { Transfer } \\
\text { compe- } \\
\text { tence }\end{array}$ \\
\hline CPKS CI & 1 & 11 & 8 & 11 & 21 \\
\hline ENPSIT & 0 & 5 & 2 & 9 & 11 \\
\hline ISO 13611/2014 & 3 & 10 & 2 & 9 & 9 \\
\hline IMI ICC & 13 & 28 & 4 & 2 & 0 \\
\hline TIME & 14 & 13 & 19 & 11 & 14 \\
\hline CPKS IM & 13 & 23 & 22 & 8 & 4 \\
\hline
\end{tabular}

with varying frequency and consequent weight. The least present is conflict resolution and mediation competence $(\mathrm{N}=48)$, which is not present in ENPSIT and barely present in CPKS CI. In fact, it is only given relevance in the documents devoted to intercultural mediators.

\subsection{Comparing the Two Slovene CPKSs}

Firstly, focusing on the two Slovene CPKSs, there is a noticeable difference between them in terms of the number of instances coded for each of the analysed competences. While all the competences are present in both texts with at least one mention, it is evident in Figure 3 that in CPKS CI, for Community Interpreters, the core competence is the transfer competence, which includes different kinds of interpreting as well as translation skills. This is followed by the linguistic competence, i.e., excellent knowledge of at least two languages (in this case Slovene and Albanian), and cultural competence. Thematic competence seems only slightly less present, although it is insisted in the CPKS that it is important for community interpreters to have enough knowledge of the topics they are asked to interpret. The conflict resolution and mediation competence is mentioned only once.

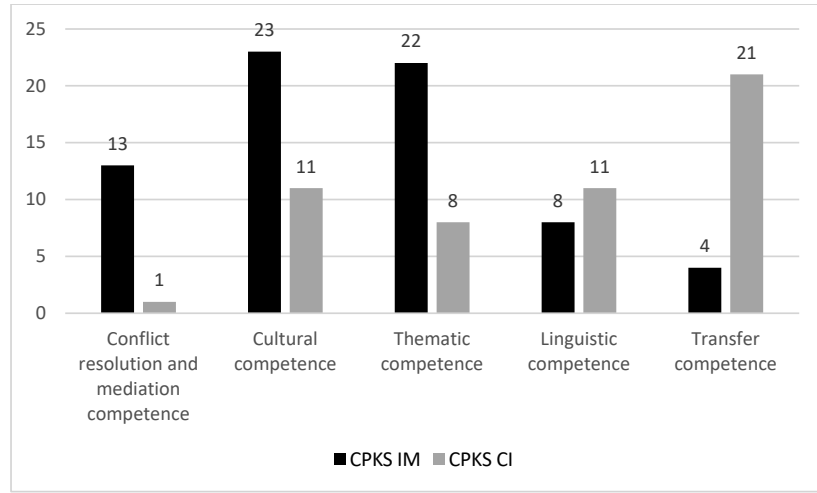

Figure 3. Comparison of CPKS IM and CPKS CI.

In CPKS IM, the two most prominently featured are cultural and thematic competences, followed by the conflict resolution and mediation competence, which is far more present 
in CPKS IM $(\mathrm{N}=13)$ compared to CPKS CI $(\mathrm{N}=1)$. Linguistic and transfer competences are the least present, with the latter being mentioned rather marginally. Such an attitude towards these two competences, which, in contrast, are considered crucial for community interpreters, seems to reflect the notion that in the Slovene standard intercultural mediators are primarily facilitators of integration and are expected to share factual knowledge about the host country with public service users. The results of the comparison thus show that there indeed is a considerable difference between the two profiles and the different tasks and activities toward which the two are oriented.

\subsection{Comparing the Slovene CPKSs with the Other Sets of Texts}

Secondly, comparing the two CPKSs with the two sets of international documents, pronounced similarities are revealed between CPKS CI and the set of competence profile documents for community interpreters (ENPSIT and ISO 13611/2014): both devote considerable attention to the transfer and linguistic competences, while the conflict resolution and mediation competence is virtually absent in these documents (mentioned only as connected to advocacy, which, according to ENPSIT and ISO 13611/2014, should be avoided). Unlike the two international documents, however, in CPKS CI cultural competence is mentioned as much as linguistic competence.

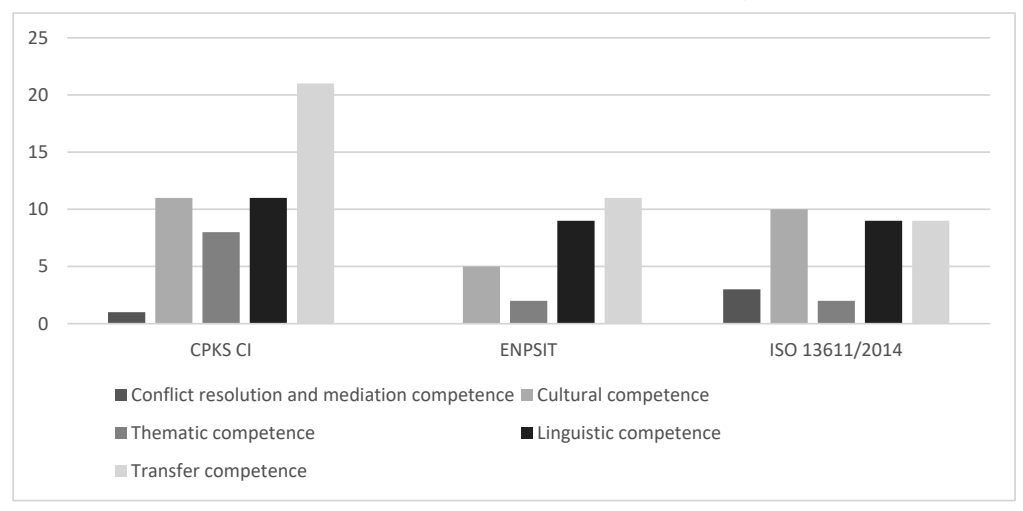

FIGURE 4. Comparison of CPKS CI with the set of profile competence documents for community interpreters.

In contrast, CPKS IM is more similar to the two documents on intercultural mediators (TIME and IMI ICC; Figure 5), especially in terms of the conflict resolution and mediation competence, which is given a prominent position in all three documents, and cultural competence, which is the most frequently mentioned competence in CPKS IM and IMI ICC. But leaving aside thematic competence, which is given the least prominence in IMI ICC, the competences in the Slovene CPKS IM seem to be much more similar to IMI ICC than to TIME. Considering that IMI ICC is a document defining intercultural mediators as professionals who perform mediation understood as "negotiation facilitated by a trusted neutral person" (International Mediation Institute 2021), while TIME defines intercultural mediation as "the facilitation of the integration process through the removal of both linguistic and cultural barriers", it is not surprising that in the former transfer competence is completely 
absent and linguistic competence is barely mentioned $(\mathrm{N}=2)$, while in the latter the two competences are much more present $(\mathrm{N}=14$ for transfer competence and $\mathrm{N}=11$ for linguistic competence). Unlike in TIME and similarly to IMI ICC, in CPKS IM transfer competence is rarely mentioned $(\mathrm{N}=4)$, while linguistic competence is slightly more present $(\mathrm{N}=8)$; both are, however, much less prominent than the other competences.

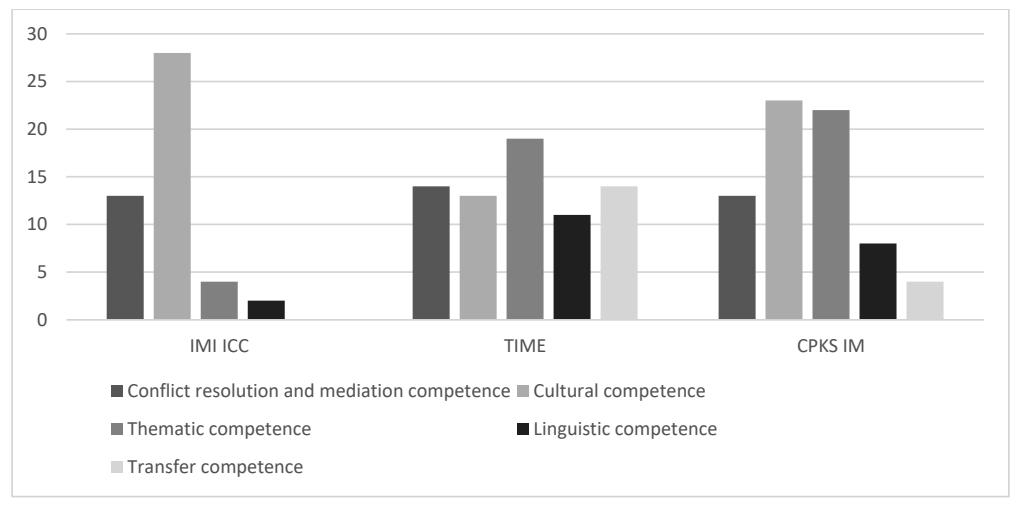

FIGURE 5. Comparison of CPKS IM with the set of profile competence documents for intercultural mediators.

\subsection{Discussion}

Today we see in several European countries a competition between two professions, both aiming to assist migrants and facilitate integration into the receiving society: the profession of a community interpreter and that of an intercultural mediator. In different European countries the profiles of these professions are defined differently, and in some environments the boundaries between the two professions are blurred. The comparison of the two Slovene and four international definitions of the profiles show that the differences in competences between the two Slovene CPKSs reflect their different positioning in the Slovene KLASIUS framework. While the main tasks of community interpreters - to enable communication between people with different languages in order to ensure proper administration/use of public services - require primarily excellent linguistic and transfer competences, for intercultural mediators it is essential to acquire a well-developed thematic competence and a cultural competence, so as to inform the public service providers and users of the particularities of the host country and/or the country of origin.

The comparisons of the Slovene definitions of the two profiles and the four international documents, defining the competences of both professions, provided an additional insight into the positioning of the Slovene standards. While the Slovene definition of a community interpreter demonstrates the essential adherence to the international standards, the comparison of Slovene standards with the two documents defining the competences of intercultural mediators proved less straightforward. The international documents defining the competences of an intercultural mediator reflect the current confusion about this profession in the labour market: IMI ICC thus defines an intercultural mediator primarily as a person who mediates and uses an interpreter when needed, while TIME merges the profession of 
an interpreter with that of a mediator. The comparison of the Slovene CPKS IM with the two international documents defining the profile of intercultural mediator shows that the Slovene standards do contain transfer competence, but to a lesser degree than the TIME competence document. In fact, the Slovene standards give the most prominent role to the cultural competence, similarly to IMI ICC competence document.

\section{Conclusion}

Despite the fact that Slovenia is a country with an exceptionally high percentage of inhabitants who can use English as a lingua franca, and the fact that numerous migrants who come to Slovenia, including those who apply for international protection, claim that they can communicate in English, various research has shown that ELF cannot be effectively used in high risk situations, such as healthcare. In such cases, high-quality language support is essential. As a response to this need, two national vocational qualifications were registered in Slovenia in 2020: that of a community interpreter for Albanian, and that of an intercultural mediator. Moreover, two additional NVQs - Community Interpreter for Arabic and Persian - are currently in preparation.

In this article, apart from examining the limitations of English as a lingua franca in public services, we have focused on the competences expressed in the two CPKSs, with the aim to establish the relative importance of the competences for each profile. We have confirmed the hypothesis that the competences are similar: in fact, the same competences are mentioned in both documents. The weight given to each competence, however, differs considerably. The greatest dissimilarities were found in the mentions of transfer and linguistic competence, which are very important for community interpreters, and conflict resolution and mediation competence, which is much more prominent with intercultural mediators. The comparison further revealed that the professional qualification for community interpreters closely followed the definitions of the profile by European associations and by the international ISO standard. The comparison of the Slovene standards for an intercultural mediator, however, showed that the Slovene vocational qualification did not follow the models where the profession of an interpreter is merged with that of a mediator, but opted for a description that defines the intercultural mediator as primarily an integration facilitator. This is also reflected in the testing procedure envisaged in both profiles: while the candidates for the national certificate of community interpreters will be tested in interpreting from and into Slovene, the candidates for the national certificate of intercultural mediators will be tested only in Slovene on their knowledge of the Slovene public institutions.

Since the CPKSs came into being in 2020 and no certification exams have taken place as of the beginning of 2021, a limitation of this study is that currently the descriptors have not been tested in practice. This will be carried out as soon as examinations start.

Finally, we hope that the establishment of the two National Vocational Qualifications is a step towards greater clarity and more clear-cut definitions of the two profiles on the labour market, which will have potential benefits both for the public service providers and users, who will be able to choose, for each task, the most appropriate professional, and will know what to expect from each of them. 


\section{References}

\section{Primary Sources}

International Mediation Institute. 2012. Criteria for Approving Programs to Qualify Mediators for IMI InterCultural Certification. https://imimediation.org/.

International Organization for Standardization (ISO). 2015. ISO 13611:2014 Interpreting - Guidelines for Community Interpreting. https://www.iso.org/standard/54082.html.

Remael, Aline, Jan Cambridge, Ulrike Fuhrer, Heidi Salaets, and Carmen Valero-Garcés. n.d. Public Service Interpreting: Minimally Required Competence in Terms of Knowledge, Skills and Attitudes. http://www .enpsit.org/uploads/1/1/3/8/113822115/t_a-document_1-competences_skills.pdf.

TIME. Train Intercultural Mediators for a Multicultural Europe. 2015. Intercultural Mediator Profile and Related Learning Outcomes. http://www.mediation-time.eu/images/TIME_O3_intercultural_mediator _profile.pdf.

Velkov Rozman, Barbara, Nike K. Pokorn, Jana Zidar Forte, Mira Grabanica, Ina Ferbežar, Katarina Bervar Strnad, Amalija Maček, Barbara Rovan, Sonja Gole Ašanin, Franci Zlatar, maja Murn, Robert Modrijan, Alida Šuligoj, and Riikka Peltonen Quijano. 2020. "A Catalogue of Professional Knowledge and Skills. Community Interpreter for Albanian 8048327011." Translated by Nataša Hirci. In Teacher Education for Community Interpreting and Intercultural Mediation. Selected Chapters., edited by Nike K. Pokorn, Maurizio Viezzi, and Tatjana Radanović Felberg, 46-61. Ljubljana: Ljubljana University Press, Faculty of Arts and National Institute for Public Health.

Velkov Rozman, Barbara, Franci Jazbec, Sonja Gole Ašanin, Robert Modrijan, Uršula Lipovec Čebron, Alida Šuligoj, Mira Grabanica, Vera Haliti, Maja Murn, Juš Škraban, Iva Perhavec, Sonja Šarac, Vera Klopčič, and Riikka Peltonen Quijano. 2020. "A Catalogue of Professional Knowledge and Skills. Intercultural Mediator 2087115 011.” Translated by Nataša Hirci. In Teacher Education for Community Interpreting and Intercultural Mediation. Selected Chapters., edited by Nike K. Pokorn, Maurizio Viezzi, and Tatjana Radanović Felberg, 62-78. Ljubljana: Ljubljana University Press, Faculty of Arts and National Institute for Public Health.

\section{Secondary Sources}

Apostolou, Fotini. 2012. “Interpreting Services for Immigrants: A New Reality in Greece." The Interpreters' Newsletter 17: 213-22. http://hdl.handle.net/10077/8632.

Bofulin, Martina, Jerneja Farkaš Lainščak, Karmen Gosenica, Ajda Jelenc, Amarjeta Keršič Svetel, Uršula Lipovec Čebron, and Juš Škraban. 2016. “Komuniciranje.” In Kulturne competence in zdravstvena oskrba. Priročnik za razvijanje kulturnih kompetenc zdravstvenih delavcev, edited by Uršula Lipovec Čebron, 197-252. Ljubljana: National Institute for Public Health.

Bowen, Sarah. 2001. Language Barriers in Access to Health Care. Ottawa: Health Canada.

California Healthcare Interpreters Association. 2002. California Standards for Healthcare Interpreters: Ethical Principles, Protocols, and Guidance on Roles \& Intervention. http://www.chiaonline.org/resources/ Pictures/CHIA_standards_manual_\%20March\%202017.pdf.

Castles, Stephen. 2000. Ethnicity and Globalization. London: Sage Publications.

Cox, Antoon. 2015. "Do You Get the Message? Defining the Interpreters' Role in Medical Interpreting in Belgium.” MonTI. Special Issue 2: 161-84. https://doi.org/10.6035/MonTI.2015.ne2.6.

European Commission. 2012. Special Eurobaromoter 386: Europeans and Their Languages. Brussels: European Commission. https://ec.europa.eu/commfrontoffice/publicopinion/archives/ebs/ebs_386 _en.pdf.

Falbo, Caterina. 2013. La comunicazione interlinguistica in ambito giuridico. Temi, problemi e prospettive di ricerca. Trieste: Edizioni Università di Trieste.

Fiedler, Sabine, and Agnes Wohlfarth. 2018. "Language Choices and Practices of Migrants in Germany: An Interview Study." Language Problems and Language Planning 42 (3): 267-87. https://doi.org/10.1075 /lplp.00023.fie. 
Gazzola, Michele, and François Grin. 2013. "Is ELF More Effective and Fair than Translation? An Evaluation of the EU's Multilingual Regime." International Journal of Applied Linguistics 23 (1): 93-107. https://doi.org/10.1111/ijal.12014.

Gorjanc, Vojko, and Nike K. Pokorn. 2013. "We Are Not Giving Up: Training Public-Service Translators and Interpreters in the Economic Crisis." mTm-A Translation Journal 5: 18-39. http://www .mtmjournal.gr/download. asp?id=457.

Gorjanc, Vojko. 2013. “Tolmačenje za skupnost in vprašanje nadnacionalne odgovornosti.” In Slovensko tolmačeslovje, edited by Vojko Gorjanc, 120-32. Ljubljana: Ljubljana University Press, Faculty of Arts. https://doi.org/10.4312/slovensko_tolmaceslovje.

Henry, Alastair. 2016. "Enablements and Constraints: Inventorying Affordances Associated with Lingua Franca English." International Journal of Bilingual Education and Bilingualism 19 (5): 488-510. https://doi.org/10.1080/13670050.2015.1014465.

HIN. 2007. National Standard Guide for Community Interpreting Services. http://www.saludycultura.uji.es/ archivos/HIN_National_Standard_Guide_for_CI_(Canada).pdf.

Huber, Ivanka, and Uršula Lipovec Čebron, eds. 2020. Standardi medkulturne mediacije v zdravstvu. Ljubljana: National Institute for Public Health.

International Mediation Institute. 2021. https://imimediation.org/.

International Organization for Standardization (ISO). 2015. ISO 13611:2014 Interpreting — Guidelines for community interpreting. https://www.iso.org/standard/54082.html.

KLASIUS. n.d. https://www.stat.si/Klasius/Default.aspx?id=13.

Linn, Andrew, Neil Bermel, and Gibson Ferguson. 2015. Attitudes Towards English in Europe: English in Europe. Berlin: De Gruyter Mouton.

Lipovec Čebron, Uršula, and Juš Škraban. 2020. “Intercultural Mediator.” In Teacher Education for Community Interpreting and Intercultural Mediation: Selected Chapters, edited by Nike K. Pokorn, Maurizio Viezzi, and Tatjana Radanović Feldberg, 38-41. Ljubljana: Ljubljana University Press, Faculty of Arts, and National institute of Public Health.

Maček, Amalija, and Mojca Schlamberger Brezar. 2019. "Oddelek za prevajalstvo na Filozofski fakulteti UL.” In Bela knjiga o prevajanju 2018: premiki na področju prevajanja, tolmačenja, podnaslavljanja in lektoriranja $v$ Sloveniji, edited by Barbara Pregelj, 52-54. Ljubljana: Društvo slovenskih književnih prevajalcev. https://www.belaknjigaoprevajanju.si/files/2019/03/Bela_knjiga_cela.pdf.

Martín, Mayte, and Mary Phelan. 2010. "Interpreters and Cultural Mediators - Different but Complementary Roles." Translocations: Migration and Social Change 6 (1): 1-20. https://doras.dcu.ie /16481/1/Martin_and_Phelan_Translocations.pdf.

Mauranen, Anna. 2014. "Lingua Franca Discourse in Academic Contexts: Shaped by Complexity." In Discourse in Context. Contemporary Applied Linguistics Volume 3, edited by John Flowerdew, 225-46. London: Bloomsbury.

Milavec Kapun, Marija, and Nike K. Pokorn. 2019. “Jezikovne kompetence zdravstvenih delavcev.” In Večjezično zdravje: Komunikacijske strategije in večkulturni stiki s tujejezičnimi bolniki v slovenskem zdravstvenem sistemu, edited by Nike K. Pokorn and Uršula Lipovec Čebron, 48-65. Ljubljana: Ljubljana University Press, Faculty of Arts.

PISG Legal Information System. 2013. Administrative Procedure Act (ZUP). Zakon o splošnem upravnem postopku (ZUP). http://www.pisrs.si/Pis.web/npbDocPdf?idPredpisa=ZAKO6643\&idPredpisaChng= ZAKO1603\&type $=$ doc\&lang=EN.

Pöchhacker, Franz. 2008. "Interpreting as Mediation.” In Crossing Borders in Community Interpreting: Definitions and Dilemmas, edited by Carmen Valero-Garcés and Anne Martin, 9-26. Amsterdam: John Benjamins.

Pokorn, Nike K., and Jaka Čibej. 2018a. "'It’s So Vital to Learn Slovene’: Mediation Choices by Asylum Seekers in Slovenia." Language Problems and Language Planning 42 (3): 265-84. https://doi.org/10 .1075/lplp.00024.pok.

—. 2018b. “'Do I Want to Learn a Language Spoken by Two Million People?’: Mediation Choices by Mid-Term and Long-Term Migrants." Language Problems and Language Planning 42 (3): 285-304. https://doi.org/10.1075/lplp.00025.pok. 
Pokorn, Nike K., and Tamara Mikolič Južnič. 2020. "Community Interpreters versus Intercultural Mediators. Is It Really All about the Ethics?” Translation and Interpreting Studies 15 (1): 80-107. https://doi.org/10.1075/tis.20027.koc.

- 2021. "From Conference to Community Interpreter Education: The Transformation of Interpreter Education in Slovenia." In Changing Paradigms and Approaches in Interpreter Training: Perspectives from Central Europe, edited by Pavol Šveda. New York: Routledge.

Pokorn, Nike K., Maurizio Viezzi, and Tatjana Radanović Feldberg, eds. 2020. Teacher Education for Community Interpreting and Intercultural Mediation. Selected Chapters. Ljubljana: Ljubljana University Press, Faculty of Arts, and National institute of Public Health.

Pokorn, Nike K., Mojca Matičič, and Marko Pokorn. 2009. "Medical Interpreting in a New Member State: A Plea for a Proactive Approach." In Spürst du, wie der Bauch rauf-runter? Fachdolmetschen im Gesundheitsbereich / Is Everything All Topsy-Turvy in Your Tummy? Health Care Interpreting, edited by Sonja Pöllabauer and Dörte Andres, 171-80. München: Meidenbauer.

Refki, Dina. H., Maria-Paz B. Avery, and Angela C. Dalton. 2008. Core Competencies for Health Care Interpreters: Research Report. https://www.albany.edu/womeningov/publications/core_competency.pdf.

RIC - National Examination Centre. n.d. "General Information” https://www.ric.si/national_vocational _qualifications/general_information/.

Schuster, Chiara. 2005. "Role and Status of Public Service Interpreters in Italy Today: A Perspective from Regional and National Policies.” In Traducción como mediación entre lenguas y culturas, edited by Carmen Valero-Garcés, 17-26. Madrid: Universidad de Alcalá.

Theodosiou, Aspasia, and Maria Aspioti, eds. 2015. Research Report on Intercultural Mediation for Immigrants in Europe. TIME Project Partnership. http://mediation-time.eu/images/TIME_O1 _Research_Report_v.2016.pdf.

TIME. Train Intercultural Mediators for a Multicultural Europe. 2015. Intercultural Mediator Profile and Related Learning Outcomes. TIME Project Partnership. http://www.mediation-time.eu/images/TIME _O3_intercultural_mediator_profile.pdf.

Verrept, Hans, and Isabelle Coune. 2016. Guide for Intercultural Mediation in Health Care. Brussels: FPS Health, Safety of the Food Chain and Environment. https://www.health.belgium.be/sites/default /files/uploads/fields/fpshealth_theme_file/2017_11_14_guide_english_0.pdf.

Verrept, Hans. 2019. Health Evidence Network Synthesis Report 64. What are the roles of intercultural mediators in health care and what is the evidence on their contributions and effectiveness in improving accessibility and quality of care for refugees and migrants in the WHO European Region? World Health Organization Regional Office for Europe. http://www.euro.who.int/_data/assets/pdf_file/0014 1406004/WHO-HEN-Report-64-Summary-Web.pdf?ua=1.

Vrečer, Natalija. 2007. Integracija kot človekova pravica. Prisilni priseljenci iz Bosne in Hercegovine v Sloveniji. Ljubljana: Založba ZRC, ZRC SAZU, Andragoški center Republike Slovenije. 